\title{
Choroby zastawki mitralnej w zespole Marfana
}

\author{
Mitral valve diseases in Marfan's syndrome
}

\author{
Wiktor Skowron, Aleksandra Majsnerowska, Magdalena Daničić \\ III Katedra i Oddział Kliniczny Kardiologii Wydziału Lekarskiego z Oddziałem Lekarsko-Dentystycznym w Zabrzu, \\ Śląski Uniwersytet Medyczny w Katowicach, Śląskie Centrum Chorób Serca w Zabrzu
}

\section{Streszczenie}

Zespół Marfana (MFS) to choroba spowodowana heterozygotycznymi mutacjami genu fibryliny 1 (FBN1). W tkankach dotkniętych mutacją dochodzi do nieprawidłowej aktywności czynnika transformującego wzrostu beta (TGF- $\beta$ ). Niedobór FBN1 i nadmierna aktywność TGF- $\beta$ prowadzą do zaburzeń struktury tkanki łącznej, co skutkuje między innymi zmianami w budowie zastawek serca. Mimo że podstaw genetycznych i patogenezy chorób zastawki mitralnej (MV) w MFS do tej pory nie wyjaśniono, ostatnie badania na myszach pozwoliły zrozumieć mechanizmy leżące u podstawy zmian fenotypowych występujących w tym zespole. W artykule omówiono częstość występowania i patologie MV obserwowane w MFS. Przedstawiono również podstawy patogenezy zmian w obrębie MV oraz aktualne możliwości leczenia farmakologicznego i chirurgicznego. Poniższa praca stanowi również przegląd piśmiennictwa na temat tego zagadnienia.

Słowa kluczowe: zespół Marfana, wypadanie płatka zastawki mitralnej, leczenie

Folia Cardiologica 2018; 13, 2: 181-187

\section{Wstęp}

Zespół Marfana (MFS, Marfan’s syndrome) to choroba genetyczna tkanki łącznej charakteryzująca się dużą zmiennością fenotypową. Przyczyną tego zespołu są mutacje w genie fibryliny 1 (FBN1), które w około $25 \%$ przypadków występują de novo. Gen odpowiedzialny za występowanie typowych dla tego zespołu objawów zlokalizowano na ramieniu długim chromosomu 15 (15q21.1). Koduje on fibrylinę - białko o masie 350 kD, które jest głównym składnikiem zewnątrzkomórkowym mikrofibryli i decyduje o prawidłowym wiązaniu czynnika transformującego wzrostu beta (TGF- $\beta$ ) w tkance łącznej. Fizjologicznie TGF- $\beta$ jest przechwytywane przez fibrylinę do tkanki łącznej. W MFS białko TGF-ß nie jest wiązane przez fibrylinę, co skutkuje uszkodzeniem włókien sprężystych, zaburzeniem w tworzeniu łańcuchów alfa kolagenu oraz substancji podstawowej tkanki łącznej. Gen powodujący powstawanie tego zespołu charakteryzuje się wysokim stopniem penetracji i zmienną ekspresją. Choroba ta dziedziczy się w sposób autosomalny dominujący, a częstość występowania MFS szacuje się na 2-3:10 000 [1]. W przebiegu MFS dochodzi do zmian w wielu narządach, jednak najbardziej charakterystyczne są patologie narządu wzroku, układu ruchu oraz serca i naczyń krwionośnych. Choroba ta objawia się między innymi przerostem kości długich, zwichnięciem soczewki oraz tętniakiem aorty. Należy również pamiętać o obserwowanych zaburzeniach w budowie i czynności zastawki mitralnej (MV, mitral valve).

\section{Historia}

Chorobę tę opisał po raz pierwszy okulista z Cincinnati w Stanach Zjednoczonych w 1876 roku [2]. W latach 90. XIX wieku pediatra z Paryża dr Antoine Berhard-Jean Marfan opisał zespół patologii układu kostno-szkieletowego

Adres do korespondencji: lek. Wiktor Skowron, III Katedra i Oddział Kliniczny Kardiologii, Wydział Lekarski z Oddziałem Lekarsko-Dentystycznym w Zabrzu, Śląski Uniwersytet Medyczny w Katowicach, Śląskie Centrum Chorób Serca, ul. M. Curie-Skłodowskiej 9, 41-800 Zabrze,

e-mail: wiktorskowron@gmail.com 
Tabela 1. Kryteria rozpoznania zespołu Marfana na podstawie zweryfikowanych kryteriów z Gandawy z 2010 roku (na podstawie [11])

Zmodyfikowane kryteria z Gandawy

$\begin{array}{ll}\text { I. Ujemny wywiad rodzinny } & \text { Il. Dodatni wywiad rodzinny } \\ \text { Ao }(Z \geq 2 \mathrm{~cm}) \text { i ektopia soczewki } & \text { Ao }(Z \geq 2 \mathrm{~cm} \text {, wiek }<20 \text {. rż.; } Z \geq 3 \mathrm{~cm} \text {, wiek } \geq 2 \text { 20. rż.) } \\ \text { lub } & \text { lub } \\ \text { Ao }(Z \geq 2 \mathrm{~cm}) \text { i patogenna mutacja genu FBN1 } & \text { Ektopia soczewki i systemic score } \geq 7 \text { pkt. } \\ \text { lub } & \\ \text { Ao }(Z \geq 2 \mathrm{~cm}) \text { i systemic score } \geq 7 \text { pkt. } & \\ \text { lub } & \\ \text { Ektopia soczewki i mutacja genu FBN1 związana } & \\ \text { z powiększeniem aorty } & \\ \text { Ao - wymiar aorty na poziomie zatoki Valsalvy; FBN1 - gen fibryliny 1; systemic score - ocena ogólnoustrojowa }\end{array}$

u małej dziewczynki i określił go mianem dolichostenomelii [3]. Termin „choroba Marfana” po raz pierwszy pojawił się w literaturze w 1929 roku [4].

W 1943 roku pojawiły się doniesienia o tętniaku rozwarstwiającym aorty w jej części wstępującej u pacjentów z MFS [5, 6]. Już w 1912 roku Salle [7] na podstawie obrazu autopsyjnego opisał przypadek kobiety z MFS i towarzyszącymi nieprawidłowościami MV. W 1955 roku McKusick, długo przed powszechnym stosowaniem echokardiografii w obrazowaniu serca i aorty, opisał patologie układu sercowo-naczyniowego u pacjentów z tym zespołem [8, 9]. W jego pracy patologie aorty stawiano na pierwszym miejscu, jednak zwrócił on również uwagę na schorzenia MV. Zauważył, że w tej grupie chorych często występują szmery skurczowe nad sercem oraz zapalenie wsierdzia. Następnie Bowers [10] opisał 6 chorych z MFS i pierwotną wadą MV, która nie wynikała z towarzyszącej niedomykalności zastawki aortalnej ani powiększenia lewego przedsionka. Zwrócił on uwagę na obraz histologiczny istoty podstawnej w płatkach MV, który był podobny do zwyrodnienia śluzowatego ściany aorty chorych z MFS. Wówczas wysunięto przypuszczenie, że choroba MV była wtórna do defektu tkanki łącznej u pacjentów z tym rozpoznaniem.

\section{Kryteria rozpoznania zespołu Marfana}

Wypadanie płatka MV, które często występuje w MFS, jest jednym z klinicznych kryteriów jego rozpoznania [11]. W 2010 roku zweryfikowano kryteria z Gandawy, podkreślając znaczenie dwóch objawów klinicznych (ektopia soczewki, powiększenie średnicy aorty) oraz mutacji genu FBN1. Zwapnienia pierścienia MV, które wcześniej włączono do mniejszych kryteriów z Gandawy, obecnie nie są w ogóle uwzględnione. Aktualnie podstawą MFS jest głównie występowanie objawów klinicznych, a stwierdzenie jedynie mutacji genetycznej nie pozwala na dokonanie rozpoznania. W ocenie ogólnoustrojowej bierze się pod uwagę następujące kryteria: między innymi zmiany w obrębie układu kostno-szkieletowego, odmę opłucnową, krótkowzroczność, rozstępy skórne oraz wypadanie płatka MV, które zwiększa wynik o 1 punkt. Mała wartość diagnostyczna schorzeń MV w kryteriach ogólnoustrojowych wiąże się z niską specyficznością tego objawu [11]. W tabelach 1 i 2 przedstawiono aktualne kryteria rozpoznania MFS wraz z oceną ogólnoustrojową.

Tabela 2. Ocena ogólnoustrojowa (systemic score) u chorych z zespołem Marfana

$\begin{array}{lc}\text { Cecha fizyczna } & \text { Punktacja* } \\ \text { Objaw nadgarstka i kciuka } & 3 \\ \text { Objaw nadgarstka lub kciuka } & 1 \\ \text { Kurza klatka piersiowa } & 2 \\ \text { Szewska klatka piersiowa lub asymetria klatki } & 1 \\ \text { piersiowej } & \\ \text { Deformacje tyłostopia } & 2 \\ \text { Płaskostopie } & 1 \\ \text { Odma opłucnowa } & 2 \\ \text { Poszerzenie przestrzeni zewnątrzoponowej krę- } & 2 \\ \text { gosłupa (dural ectasia) } & \\ \text { Zwichnięcie panewki kości udowej } & 2 \\ \text { Zmniejszony stosunek górnego segmentu ciała } & 1 \\ \text { do dolnego i zwiększony stosunek rozpostar- } & \\ \text { tych ramion do długości ciała } & \\ \text { Skolioza lub kyfoza piersiowo-lędźwiowa } & 1 \\ \text { Zmniejszony wyprost w stawach łokciowych } & 1 \\ \text { 3-5 cech dysmorficznych twarzoczaszki } & 1 \\ \text { Rozstępy skórne } & 1 \\ \text { Krótkowzroczność } & 1 \\ \text { Wypadanie płatka zastawki mitralnej } & \\ \text { *wynik z pkt. uważa się za dodatnią ocenę ogólnoustrojową } & \end{array}$




\section{Choroby zastawki mitralnej w zespole Marfana}

Wydłużenie jednego lub obu płatków mitralnych, często z towarzyszącym zwyrodnieniem śluzowatym oraz uginaniem części płatka do lewego przedsionka przy zachowanej koaptacji (billowing), to typowe nieprawidłowości MV występujące w tej grupie chorych [12]. Chirurgiczna ocena morfologii MV pacjentów z MFS wykazała, że patologie tej zastawki rozwijają się w młodszym wieku (41 v. 57 lat; $p<0,0001)$, a przedni płatek mitralny jest u nich dłuższy niż u pacjentów bez MFS (40 v. 33 mm; $p<0,0007$ ) [13].

\section{Częstość występowania dysfunkcji zastawki mitralnej w zespole Marfana}

W literaturze opisywane są różne częstości występowania patologii MV u chorych z MFS. Pyeritz i Wappel [14] w kohortowym badaniu obejmującym 166 chorych z MFS opisują występowanie zjawisk osłuchowych, które mogłyby sugerować niedomykalność MV u 52\% pacjentów. U 68\% chorych występowanie nieprawidłowości zastawki potwierdzono w badaniu echokardiograficznym. Przede wszystkim obserwowano wypadanie płatka MV (prolaps) (ryc. 1). Zerwanie nici ścięgnistych w tej grupie chorych występowało rzadko [14]. Z kolei Taub i wsp. [15] opisują grupę 90 chorych z MFS, w której tylko u 28\% pacjentów stwierdzono wypadanie i pogrubienie płatków MV. W tej grupie chorych często obserwowano również poszerzenie aorty [15]. Detaint i wsp. [16] donoszą, że wypadanie płatka MV obserwuje się u 77\% chorych z MFS i w $61 \%$ przypadków towarzyszy mu niedomykalność tej zastawki (ryc. 2). W tym dużym jednoośrodkowym rejestrze obejmującym 1013 chorych MFS potwierdzono w badaniu genetycznym.

Duża rozbieżność patologii MV w rejestrach wynika z różnych definicji zmian w obrębie tej zastawki. Podsumowując, u chorych z MFS częstość występowania dysfunkcji

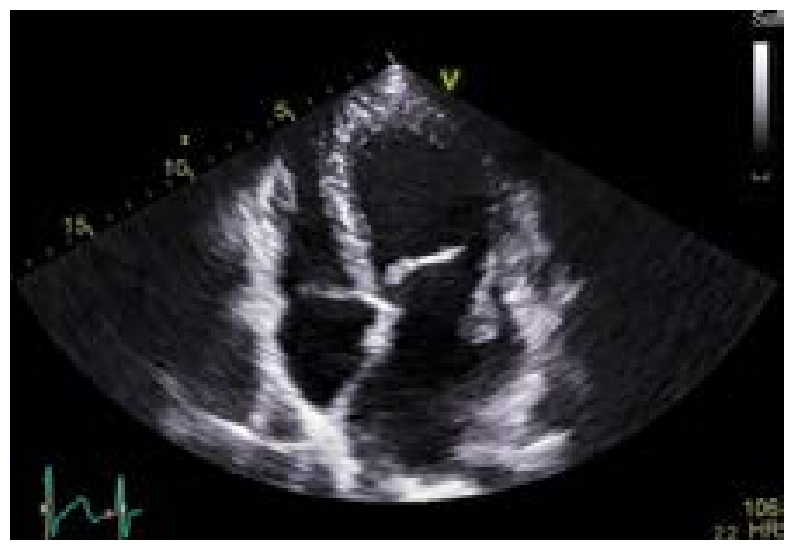

Rycina 1. Wypadanie pogrubiałego i nadmiernie wydłużonego tylnego płatka zastawki mitralnej u chorego z zespołem Marfana

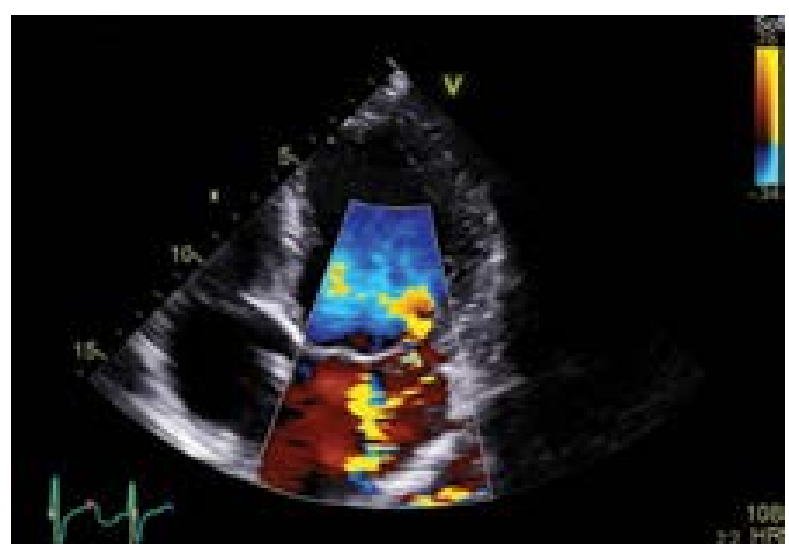

Rycina 2. Istotna hemodynamicznie niedomykalność zastawki mitralnej w przebiegu wypadania tylnego płatka zastawki mitralnej u chorego z zespołem Marfana

MV może sięgać nawet 75\% i jest zjawiskiem stosunkowo częstym.

Stwierdzono, że zmiany w obrębie MV obserwuje się już w okresie noworodkowym. W jednym z badań opisano 22 dzieci ze zdiagnozowanym MFS, u których wypadanie płatka MV w pierwszych 3 miesiącach życia występowało z częstością 82\%, a towarzysząca mu niedomykalność była czynnikiem złego rokowania [17]. Sisk i wsp. [18] opisali 15 kolejnych dzieci z MFS. W tej grupie u 60\% badanych występowało poszerzenie aorty, a niedomykalność MV obserwowano u 33\% i była ona również czynnikiem złego rokowania [18]. Na podstawie danych z międzynarodowej bazy MFS wiadomo, że istnieje korelacja między wiekiem dziecka a występowaniem wypadania płatka MV. Z wiekiem zmniejsza się częstość występowania dysfunkcji tej zastawki, która jest obserwowana aż u 73\% noworodków (do 4. tygodnia życia), ale jedynie u $62 \%$ chorych między 4. tygodniem a 10. rokiem życia i u $59 \%$ chorych między 10. a 18. rokiem życia [19].

Częstość występowania schorzeń MV w przebiegu MFS powinna być porównywalna z częstością występowania w zdrowej populacji. W badaniu Framingham Heart Study stwierdzono, że klasyczne wypadanie płatków MV, definiowane jako przesunięcie o więcej niż $2 \mathrm{~mm}$ powyżej linii pierścienia mitralnego podczas skurczu lewej komory, z ich pogrubieniem powyżej $5 \mathrm{~mm}$, występowało z częstością 1,3\%. W przypadku zmodyfikowanej definicji, zgodnie z którą grubość płatków była mniejsza lub równa $5 \mathrm{~mm}$, częstość ta wynosiła jedynie 1,1\% [20]. We wcześniejszych publikacjach sugerowano, że ta dysfunkcja u osób zdrowych występowała częściej, jednak nie uwzględniano w nich trójwymiarowej struktury zastawki oraz jej pierścienia [21]. Wiadomo, że wypadanie płatka (prolaps) MV występuje rodzinnie. Do tej pory nie opisano jednak genów, których mutacje wiążą się tym schorzeniem. Opisano jedynie trzy loci na chromosomach (chromosom 
16p12.1-p11.2, chromosom 11p15.4 i 13 q31.3-q32.1), które mogą być związane z bezobjawowym rodzinnym występowaniem „prolapsu mitralnego” [22-24].

\section{Etiologia chorób zastawki mitralnej w zespole Marfana}

Niektóre patologie, takie jak ektopia soczewki, występujące w MFS mogą być łatwo wytłumaczone nieprawidłowościami strukturalnymi białek spowodowanymi mutacją genu FBN1. Jednak nie można tak tłumaczyć patologii MV występujących w tym zespole. Zarówno w badaniach na myszach, jak i u ludzi potwierdzono, że mutacja genu FBN1 powoduje zmniejszenie wiązania utajonego TGF- $\beta$ w macierzy zewnątrzkomórkowej, co prowadzi do wzrostu aktywności tego czynnika wzrostu. Judge i wsp. [25] przypuszczają, że wydłużenie i nadmierne pogrubienie płatków MV może mieć związek ze zwiększeniem aktywności TGF- $\beta$. Zmienność chorób MV w rodzinach z taką samą mutacją genu FBN1 sugeruje jednak wpływ dodatkowych czynników środowiskowych oraz genetycznych.

\section{Leczenie farmakologiczne}

Ze względu na fakt, że w rozwoju MFS ważną rolę odgrywa białko TGF- $\beta$, poszukiwano czynników fizjologicznie wpływających na jego aktywność. Stwierdzono liczne interakcje między angiotensyną II i TGF- $\beta$. Stosowanie losartanu (selektywnego antagonisty receptora dla angiotensyny II typu 1 - $\mathrm{AT}_{1}$ ) u myszy z mutacją genu FBN1 spowodowało zmniejszenie aktywności TGF- $\beta$ oraz istotną redukcje średnicy aorty w porównaniu z myszami, które leczono antagonistami receptorów adrenergicznych w dawkach wywołujących podobny efekt hemodynamiczny. Stosowanie losartanu ograniczało również objawy fenotypowe w tkankach nienależących do układu sercowo-naczyniowego, między innymi w pęcherzykach płucnych i mięśniach szkieletowych [26]. Toczą się badania na zwierzętach z MFS oraz z udziałem chorych na MFS, których celem jest ocena wpływu selektywnych antagonistów receptora $\mathrm{AT}_{1}$ oraz antagonistów receptora adrenergicznego na przeżycie, zmniejszenie wymiarów aorty oraz patologie MV [27].

W badaniach klinicznych służących ocenie możliwości leczenia farmakologicznego chorych z MFS stosuje się leki zmniejszające aktywność angiotensyny II. Istnieją trzy kategorie tych leków: inhibitory enzymu konwertazy angiotensyny, inhibitory reniny oraz sartany, które są selektywnymi antagonistami receptora $\mathrm{AT}_{1}$ i pozwalaja na ciągłe pobudzanie receptora $\mathrm{AT}_{2}$. Te ostatnie, poprzez pobudzenie receptora $A T_{2}$, być może wpływają na hamowanie proliferacji komórek mięśni gładkich, zmniejszenie włóknienia oraz produkcję metaloprotein w tkankach aorty. W badaniach na myszach z mutacja genu FBN1 leczonych enalaprilem i losartanem $w$ dawkach wywołujących taki sam efekt hemodynamiczny dowiedziono, że losartan jest skuteczniejszy w zmniejszaniu wymiarów aorty poprzez zmianę architektury jej tkanek [28].

Istnieją również badania potwierdzające zmniejszenie patologicznego wydłużenia płatków MV oraz stopnia jej niedomykalności u myszy z mutacją genu FBN1. Stosowano $w$ nich przeciwciała neutralizujące TGF- $\beta$. Stwierdzono, że stosowanie u myszy tych przeciwciał ogranicza wiele fenotypowych objawów MFS [28].

Podsumowując, w przedstawionych badaniach najlepiej udokumentowaną pozycję w leczeniu farmakologicznym MFS ma losartan. Wpływa on nie tylko na zmiany w obrębie MV, ale również na patologie w obrębie ściany aorty.

\section{Leczenie chirurgiczne}

Uważa się, że zabiegi naprawcze MV są preferowaną metodą leczenia chirurgicznego. W porównaniu $z$ wymiana naprawa zastawki zapewnia lepsze wyniki pooperacyjne oraz przeżycie długoterminowe. U pacjentów z MFS naprawa MV nie była preferowanym sposobem leczenia, co wynikało z braku zrozumienia patomechanizmów powstania niedomykalności w tej grupie chorych. Co więcej, wielu chorym z MFS operowanym z powodu niedomykalności MV wszczepiono wcześniej mechaniczne protezy zastawki aortalnej i w związku z tym stosowano przewlekle doustne leki przeciwkrzepliwe. W związku z tym częściej decydowano o wymianie MV na proteze mechaniczną. Należy jednak zaznaczyć, że zabiegi naprawcze MV u pacjentów z MFS, w porównaniu z jej wymianą na proteze mechaniczną, wiążą się z podobną, niską śmiertelnością operacyjną [29]. Helder i wsp. [30] opisują retrospektywne badanie 61 pacjentów z MFS i istotną hemodynamicznie niedomykalnością MV, których leczono kardiochirurgicznie. Niezależnie od rodzaju zabiegu chirurgicznego (plastyka MV v. jej wymiana) śmiertelność operacyjna wyniosła 1,6\% (1/61) [31]. Ryzyko zgonu w grupie chorych z MFS było podobne do ryzyka zgonu w populacji ogólnej pacjentów poddawanym operacjom MV, co potwierdzają doniesienia z piśmiennictwa [29, 32, 33]. Różnice w rokowaniu u chorych poddawanych zabiegom operacyjnym dotyczą przede wszystkim obserwacji odległej. Helder i wsp. [30] opisują, że $u$ chorych z MFS po naprawie MV 10-letnie przeżycie wyniosło $80 \%(p=0,01)$, a po wymianie zastawki - jedynie $41 \%(p=0,01)$. Autorzy ci sugerują, że tak duża różnica w zakresie śmiertelności w obserwacji odległej może wynikać ze zmian zachodzących w obrębie lewej komory. Naprawa zwyrodniałej MV pozwala bowiem na zachowanie geometrii lewej komory, co przekłada się na poprawę jej funkcji skurczowej. Równocześnie w analizie statystycznej nie stwierdzono innych czynników wpływających na tę różnicę w rokowaniu odległym. Nie wykazano również związku z powikłaniami zakrzepowo-zatorowymi, które występuja u chorych z protezami mechanicznymi [34]. 
U chorych z MFS oraz z innymi chorobami tkanki łącznej kwestionowano także trwałość zabiegu naprawczego na MV. Wynikało to z patomechanizmu tej dysfunkcji. Sugerowano, że niedomykalność MV w MFS wynika głównie z patologii przedniego płatka mitralnego. Jednak Bhudia i wsp. [33] stwierdzili, że u chorych z MFS wypadanie przedniego i tylnego płatka mitralnego występuje z taką samą częstością, jak u chorych ze zwyrodnieniową chorobą MV. Być może, patomechanizm niedomykalności MV wpływa na trwałość zabiegów naprawczych u chorych z MFS. Dodatkowo złożoność korekcji przedniego płatka może prowadzić do wyższego ryzyka nawrotu niedomykalności mitralnej w obserwacji odległej [35].

Naprawa MV u pacjentów z MFS może być mniej trwała, gdyż nie eliminuje ona potencjalnego defektu tkankowego. Wyniki badań histologicznych tkanek MV u chorych z MFS sugerują podobieństwo do tkanek zwyrodnieniowej MV, a mechanizm powstawania tych zmian jest zbliżony $[36,37]$. Oba procesy patologiczne wydają się związane z nieprawidłowościami fibryliny i zaburzeniem drogi TGF- $\beta$ [38]. Z kolei Nasuti i wsp. [39] opisali nieprawidłowości fibryliny w płatkach MV u chorych z MFS, w których białka strukturalne są bardziej rozproszone niż w płatkach zastawki zdrowej populacji. Gillinov i wsp. [29] opisali grupe 36 pacjentów z MFS poddawanych zabiegom operacyjnym MV (29 napraw, 7 wymian). Z tej grupy tylko jeden pacjent wymagał reoperacji MV z powodu zapalenia wsierdzia. Fuzellier i wsp. [32] z kolei opisali 33 pacjentów z MFS, którzy byli operowani z powodu dysfunkcji MV (32 naprawy, 1 wymiana). U 87\% z nich nie obserwowano niedomykalności MV w ciągu 10 lat obserwacji. Zarówno w omawianych grupach chorych, jak i w badaniu Heldera i wsp. [30] nie stwierdzono statystycznie istotnej różnicy pod względem trwałości zabiegów naprawczych MV u chorych z MFS i chorobami zwyrodnieniowymi tej zastawki. Trwałość zabiegów naprawczych i rokowanie odległe u pacjentów z MFS sugerują, że naprawa MV w tej grupie chorych może być korzystna nawet u osób, którym wcześniej wszczepiono mechaniczne protezy aortalne.

\section{Podsumowanie}

Autorzy zaleceń Europejskiego Towarzystwa Kardiologicznego (ESC, European Society of Cardiology) dotyczących leczenia chorych z MFS skoncentrowali się głównie na schorzeniach aorty. Należy jednak pamiętać o zmianach w obrębie MV, które często występują w tej grupie chorych. Celem leczenia farmakologicznego pacjentów z MFS powinno być nie tylko zmniejszenie wymiaru aorty, ale również wpływ na potencjalną dysfunkcję MV. Prowadzone badania kliniczne ostatecznie posłużą ocenie wpływu losartanu i antagonistów receptora adrenergicznego na stopień redukcji niedomykalności MV u chorych z MFS. Obecnie standardową metodą postępowania w istotnej hemodynamicznie niedomykalności MV jest leczenie chirurgiczne. U chorych z MFS zabiegi naprawcze MV powinny być rozważane w pierwszej kolejności. W odniesieniu do takiego sposobu postępowania udokumentowano lepsze rokowanie odległe przy niskiej śmiertelności okołooperacyjnej. Niewątpliwie na decyzję o sposobie i możliwościach leczenia dysfunkcji MV w MFS wpływa lepsze zrozumienie patogenezy tego schorzenia.

\section{Konflikt interesów}

Autorzy deklarują brak konfliktu interesów.

\section{Abstract}

Marfan's syndrome (MFS) is a disease caused by heterozygous mutation in the fibrillin 1 gene. Tissues affected by this mutation show improper transforming growth factor beta (TGF- $\beta$ ) signalling. Fibrillin 1 deficiency and excess activation of TGF- $\beta$ cause changes in collagen tissue structure, leading to alterations in heart valves architecture. Although precise pathogenetic mechanisms of mitral valve (MV) diseases in MFS remain unclear, recent studies on mice have helped us to understand the mechanisms of phenotype changes occurring in patients with MFS. In this article we present the prevalence of MV pathologies observed in MFS, basic pathogenetic mechanisms of MV dysfunction as well as currently available options for pharmacological and surgical treatment. The article also provides an overview of currently available literature on MFS.

Key words: Marfan's syndrome, mitral valve prolapse, treatment

Folia Cardiologica 2018; 13, 2: 181-187 


\section{Piśmiennictwo}

1. Chiu $\mathrm{HH}, \mathrm{Wu} \mathrm{MH}$, Chen $\mathrm{HC}$, et al. Epidemiological profile of Marfan syndrome in a general population: a national database study. Mayo Clin Proc. 2014; 89(1): 34-42, doi: 10.1016/j.mayocp.2013.08.022, indexed in Pubmed: 24388020.

2. Williams E. Rare cases, with practical remarks. Trans Am Ophthalmol Soc. 1875; 2: 291-301, indexed in Pubmed: 25258802.

3. Marfan A. Un cas de déformation congénitgale des quatres membres, plus prononcée aux extremités, caractérisée par l'allongement des os avec un certain degré d'amincissiment. Bulletins et memoires de la Société medicale des hôpitaux de Paris. 1896; 13: 220-228.

4. Ruettimann B, Steinmann BA. Marfan his life and times. Europ J Pediat. 1996; 155: 725-726.

5. Baer RW, Taussig HB, Oppenheimer EH. Congenital aneurysmal dilatation of the aorta associated with arachnodactyly. Bull Hopkins Hosp. 1943; 72: 309-331.

6. Etter LE, Glover LP. Arachnodactyly complicated by dislocated lens and death from rupture of dissecting aneurysm of the aorta. JAMA. 1943; 23: 88-89.

7. Salle V. Uber einen Fall von angeborener Abnormalen grosse der Extrernitaten mit einem an Akromegalie erinnernden Symptomenkomplex. J ahrb f Kinderh. 1912; 75: 540-548.

8. Baer RW, Taussig HB, Oppenheimer EH. Congenital aneurysmal dilatation of the aorta associated with arachnodactyly. Bulletin of the Johns Hopkins Hospital. 1943; 72: 309-317.

9. McKusick VA. The cardiovascular aspects of Marfan's syndrome: a heritable disorder of connective tissue. Circulation. 1955; 11(3): 321-342, indexed in Pubmed: 14352380.

10. Bowers D, Bowers D. Primary abnormalities of the mitral valve in Marfan's syndrome. Electrocardiographic findings. Br Heart J. 1969; 31(6): 676-678, indexed in Pubmed: 5358146.

11. Loeys BL, Dietz HC, Braverman AC, et al. The revised Ghent nosology for the Marfan syndrome. J Med Genet. 2010; 47(7): 476-485, doi: 10.1136/jmg.2009.072785, indexed in Pubmed: 20591885.

12. Barlow JB, Bosman CK. Aneurysmal protrusion of the posterior leaflet of the mitral valve. An auscultatory-electrocardiographic syndrome. Am Heart J. 1966; 71(2): 166-178, indexed in Pubmed: 4159172.

13. Bhudia SK, Troughton R, Lam BK, et al. Mitral valve surgery in the adult Marfan syndrome patient. Ann Thorac Surg. 2006; 81(3): 843-848, doi: 10.1016/j.athoracsur.2005.08.055, indexed in Pubmed: 16488682.

14. Pyeritz RE, Wappel MA. Mitral valve dysfunction in the Marfan syndrome. Clinical and echocardiographic study of prevalence and natural history. Am J Med. 1983; 74(5): 797-807, indexed in Pubmed: 6837604.

15. Taub CC, Stoler JM, Perez-Sanz T, et al. Mitral valve prolapse in Marfan syndrome: an old topic revisited. Echocardiography. 2009; 26(4): 357-364, doi: 10.1111/j.1540-8175.2008.00825.x, indexed in Pubmed: 19054044.

16. Détaint D, Faivre L, Collod-Beroud G, et al. Cardiovascular manifestations in men and women carrying a FBN1 mutation. Eur Heart J. 2010; 31(18): 2223-2229, doi: 10.1093/eurheartj/ehq258, indexed in Pubmed: 20709720.

17. Morse RP, Rockenmacher S, Pyeritz RE, et al. Diagnosis and management of infantile Marfan syndrome. Pediatrics. 1990; 86(6): 888-895, indexed in Pubmed: 2251026.

18. Sisk HE, Zahka KG, Pyeritz RE. The Marfan syndrome in early childhood: analysis of 15 patients diagnosed at less than 4 years of age. Am J Cardiol. 1983; 52(3): 353-358, indexed in Pubmed: 6869287.

19. Faivre L, Masurel-Paulet A, Collod-Béroud G, et al. Clinical and molecular study of 320 children with Marfan syndrome and related type I fibrillinopathies in a series of 1009 probands with pathogenic FBN1 mutations. Pediatrics. 2009; 123(1): 391-398, doi: 10.1542/ /peds.2008-0703, indexed in Pubmed: 19117906.

20. Freed LA, Levy D, Levine RA, et al. Prevalence and clinical outcome of mitral-valve prolapse. N Engl J Med. 1999; 341(1): 1-7, doi: 10.1056/ /NEJM199907013410101, indexed in Pubmed: 10387935.

21. Levine RA, Triulzi MO, Harrigan P, et al. The relationship of mitral annular shape to the diagnosis of mitral valve prolapse. Circulation. 1987; 75(4): 756-767, indexed in Pubmed: 3829339.

22. Disse S, Abergel E, Berrebi A, et al. Mapping of a first locus for autosomal dominant myxomatous mitral-valve prolapse to chromosome 16p11.2-p12.1. Am J Hum Genet. 1999; 65(5): 1242-1251, doi: 10.1086/302624, indexed in Pubmed: 10521289.

23. Freed LA, Acierno JS, Dai D, et al. A locus for autosomal dominant mitral valve prolapse on chromosome 11p15.4. Am J Hum Genet. 2003; 72(6): 1551-1559, doi: 10.1086/375452, indexed in Pubmed: 12707861.

24. Nesta F, Leyne M, Yosefy C, et al. New locus for autosomal dominant mitral valve prolapse on chromosome 13: clinical insights from genetic studies. Circulation. 2005; 112(13): 2022-2030, doi: 10.1161/ /CIRCULATIONAHA.104.516930, indexed in Pubmed: 16172273.

25. Judge DP, Rouf R, Habashi J, et al. Mitral valve disease in Marfan syndrome and related disorders. J Cardiovasc Transl Res. 2011; 4(6): 741-747, doi: 10.1007/s12265-011-9314-y, indexed in Pubmed: 21866385.

26. Habashi JP, Judge DP, Holm TM, et al. Losartan, an AT1 antagonist, prevents aortic aneurysm in a mouse model of Marfan syndrome. Science. 2006; 312(5770): 117-121, doi: 10.1126/science.1124287, indexed in Pubmed: 16601194.

27. Lacro RV, Dietz HC, Wruck LM, et al. Pediatric Heart Network Investigators. Rationale and design of a randomized clinical trial of beta-blocker therapy (atenolol) versus angiotensin II receptor blocker therapy (losartan) in individuals with Marfan syndrome. Am Heart J. 2007; 154(4): 624-631, doi: 10.1016/j.ahj.2007.06.024, indexed in Pubmed: 17892982.

28. Habashi JP, Doyle JJ, Holm TM, et al. Angiotensin II type 2 receptor signaling attenuates aortic aneurysm in mice through ERK antagonism. Science. 2011; 332(6027): 361-365, doi: 10.1126/science.1192152, indexed in Pubmed: 21493863.

29. Gillinov AM, Hulyalkar A, Cameron DE, et al. Mitral valve operation in patients with the Marfan syndrome. J Thorac Cardiovasc Surg. 1994; 107(3): 724-731, indexed in Pubmed: 8127102.

30. Helder MRK, Schaff HV, Dearani JA, et al. Management of mitral regurgitation in Marfan syndrome: Outcomes of valve repair versus replacement and comparison with myxomatous mitral valve disease. J Thorac Cardiovasc Surg. 2014; 148(3): 1020-4; discussion 1024, doi: 10.1016/j.jtcvs.2014.06.046, indexed in Pubmed: 25129593.

31. Rankin JS, He X, O'Brien SM, et al. The Society of Thoracic Surgeons risk model for operative mortality after multiple valve surgery. Ann Thorac Surg. 2013; 95(4): 1484-1490, doi: 10.1016/j.athoracsur.2012.11.077, indexed in Pubmed: 23522221.

32. Fuzellier JF, Chauvaud SM, Fornes $P$, et al. Surgical management of mitral regurgitation associated with Marfan's syndrome. Ann Thorac Surg. 1998; 66(1): 68-72, indexed in Pubmed: 9692440. 
33. Bhudia SK, Troughton R, Lam BK, et al. Mitral valve surgery in the adult Marfan syndrome patient. Ann Thorac Surg. 2006; 81(3): 843-848, doi: 10.1016/j.athoracsur.2005.08.055, indexed in Pubmed: 16488682.

34. Enriquez-Sarano M, Schaff HV, Orszulak TA, et al. Valve repair improves the outcome of surgery for mitral regurgitation. A multivariate analysis. Circulation. 1995; 91(4): 1022-1028, indexed in Pubmed: 7850937.

35. Suri RM, Schaff HV, Dearani JA, et al. Survival advantage and improved durability of mitral repair for leaflet prolapse subsets in the current era. Ann Thorac Surg. 2006; 82(3): 819-826, doi: 10.1016/j. athoracsur.2006.03.091, indexed in Pubmed: 16928491.

36. Liu AC, Joag VR, Gotlieb Al. The emerging role of valve interstitial cell phenotypes in regulating heart valve pathobiology. Am J Pathol. 2007;
171(5): 1407-1418, doi: 10.2353/ajpath.2007.070251, indexed in Pubmed: 17823281.

37. Barth PJ, Köster H, Moosdorf R. CD34+ fibrocytes in normal mitral valves and myxomatous mitral valve degeneration. Pathol Res Pract. 2005; 201(4): 301-304, doi: 10.1016/j.prp.2005.02.001, indexed in Pubmed: 15991836.

38. Judge DP, Rouf R, Habashi J, et al. Mitral valve disease in Marfan syndrome and related disorders. J Cardiovasc Transl Res. 2011; 4(6): 741-747, doi: 10.1007/s12265-011-9314-y, indexed in Pubmed: 21866385.

39. Nasuti JF, Zhang PJ, Feldman MD, et al. Fibrillin and other matrix proteins in mitral valve prolapse syndrome. Ann Thorac Surg. 2004; 77(2): 532-536, doi: 10.1016/S0003-4975(03)01584-4, indexed in Pubmed: 14759433. 